\title{
HUBUNGAN IMPLEMENTASI MANAJEMEN BERBASIS SEKOLAH DENGAN EFEKTIVITAS SEKOLAH MENENGAH ATAS NEGERI SE-KOTA PALANGKA RAYA
}

\author{
(Relationship Between Implementation of School Based Management \\ Toward the School Effectiveness at State Senior High Schools in Palangka Raya)
}

\author{
SUNIATI \\ Dosen Program Studi Pendidikan Guru Sekolah Dasar Fakultas Keguruan dan IImu Pendidikan \\ Universitas Muhammadiyah Palangkaraya
}

\begin{abstract}
This research was conducted at State Senior High Schools in Palangka Raya, central Kalimantan, the purpose of this research is to know whether there is any significant relationship between Implementation of school based management toward the school effectiveness at State Senior High Schools in Palangka Raya simultaneously. This research was designed by using the correlation quantitative approach through survey method. Target population are all teachers at State Senior High Schools in Palangka Raya, which amount 163 teachers. The total number of research sample was 115 teachers. Sample was taken by using randomized proportional sampling technique.

The result of this research conclude that there was a significant relationship between Implementation of school based management with the School Effectiveness, represented by the linear regression $\hat{Y}=a+b X=79,85+2,57 X$ and correlation coefficient $r_{y}=0.976$ which is significant at $\alpha=0,05$. This result of this study is expected to be useful for improving the school effectiveness in achieving its vision and mission of the objective of effective and efficient school. It is therefore, necessary to effectively improve school is through the understanding of good teachers in the implementation of school management.
\end{abstract}

Keywords: school based mannagement, school effectiveness

\begin{abstract}
ABSTRAK
Penelitian ini dilaksanakan di SMA Negeri se-Kota Palangka Raya, Kalimantan Tengah yang bertujuan untuk mengetahui apakah ada hubungan yang signifikan antara Implementasi manajemen berbasis sekolah terhadap efektivitas sekolah di SMA Negeri se-Kota Palangka Raya secara simultan. Penelitian ini dirancang dengan menggunakan pendekatan kuantitatif korelasional melalui metode survei. Populasi target adalah semua guru di SMA Negeri se-Kota Palangka Raya yang berjumlah 163 guru. Jumlah sampel penelitian adalah 115 guru. Sampel diambil dengan menggunakan teknik proporsional random sampling.

Hasil penelitian ini menyimpulkan bahwa ada hubungan yang signifikan antara Implementasi manajemen berbasis sekolah dengan Efektivitas Sekolah, dengan persamaan regresi $\hat{Y}=79,85+2,57 X$ dan koefisien korelasi $r y=0,976$ yang signifikan pada $\alpha=0,05$. Hasil penelitian ini diharapkan dapat bermanfaat untuk meningkatkan efektivitas sekolah dalam mencapai visi dan misi tujuan sekolah yang efektif dan efisien. Oleh karena itu perlu diupayakan cara peningkatan efektivitas sekolah yakni melalui pemahaman guru yang baik terhadap pelaksanaan manajemen berbasis sekolah.
\end{abstract}

Kata kunci: manajemen berbasis sekolah, efektivitas sekolah

\section{PENDAHULUAN}

Penyelenggaraan sekolah yang efektif merupakan tangggung jawab bersama antara Pemerintah, Pemerintah Daerah, dan masyarakat sebagai amanat desentralisasi pendidikan sebagaimana termuat dalam Undang - Undang nomor 22 Tahun 1999 tentang Pemerintah Daerah yang menyebutkan bahwa "Pendidikan dan Kebudayaan telah ditetapkan sebagai salah satu bidang pemerintahan yang wajib 
dilaksanakan oleh Pemerintah Kabupaten/Kota". Perkembangan desentralisasi pendidikan ini akhirnya diperkuat pula dalam UU Nomor 32 tahun 2004 tentang Pemerintah Daerah. Meskipun dalam penyelenggaraan pendidikan terjadi pembagian tugas dan kewenangan antara Pemerintah Pusat dan Pemerintah Daerah, namun kebijakan dalam bentuk standarisasi mutu, pedoman dan prosedur, serta kriteria pengelolaan pendidikan tetap menjadi tanggung jawab Menteri Pendidikan Nasional sebagaimana ditetapkan dalam Peraturan Pemerintah Nomor 19 tahun 2005 tentang Standar Nasional Pendidikan.

Selama ini sistem pendidikan dikembangkan oleh para eksekutif birokrasi dengan sistem yang monolitik sehingga kurang melibatkan pemikiran dan aspirasi para pendidik dan tenaga kependidikan maupun tuntutan kebutuhan masyarakat. Kepala sekolah dan Guru yang selama ini difungsikan sebagai palaksana, perlu diikutsertakan sebagai pengambil prakarsa, inisiatif dalam pengembangan sekolah. Begitupun para siswa, tidak boleh dipandang sebagai obyek didik yang tidak boleh berbeda pendapat dengan pendapat guru. Unsur manusia dalam pendidikan perlu ditempatkan sebagai manusia yang utuh dan mampu membentuk diri, serta bukan manusia yang dibentuk. Cita-cita membangun sistem pendidikan yang menjamin kebesaran bangsa, menempatkan keragaman budaya dan keunggulan lokal sebagai kekuatan bangsa dalam bersaing dan bersanding dengan negara lain perlu dimaknai strategi implementasinya sehingga dapat menciptakan sumber daya manusia yang berkualitas.
Pentingnya pemahaman terhadap keefektifan sekolah tidak saja dalam kaitan dengan meningkatkan mutu pendidikan tetapi juga sesuai dengan kebijakan nasional yaitu desentralisasi pendidikan dalam rangka pelaksanaan otonomi daerah. Berkenaan dengan desentralisasi pendidikan tersebut, di bidang pendidikan dasar dan menengah, Depdiknas telah menyiapkan konsep otonomi sekolah yaitu manajemen berbasis sekolah. Dengan konsep ini, pemerintah tidak hanya berharap pada meningkatnya mutu pendidikan melainkan juga tercapainya pemerataan, relevansi, dan efisiensi penyelenggaraan pendidikan.

Dalam konteks MBS, sekolah harus meningkatkan keikutsertaan masyarakat dalam pengelolaannya guna meningkatkan kualitas dan efisiensinya. Meskipun demikian, otonomi pendidikan dalam konteks MBS harus dilakukan dengan selalu mengacu pada akuntabilitas terhadap masyarakat, orangtua, siswa, maupun pemerintah pusat dan daerah.

Penerapan manajemen berbasis sekolah (MBS) serta perintisan sekolah yang berbasis keunggulan lokal menuntut perubahan dalam kepemimpinan Kepala Sekolah dalam mengelola sumberdaya pendidikan di daerah masing masing. Kepala Sekolah harus mampu meningkatkan mutu pendidikan melalui berbagai pendekatan yang berbasis kepada masyarakat (community based education) dan kebutuhan sekolah (school based management). Perubahan sistem sentralisasi ke desentralisasi memberikan lebih banyak wewenang kepada Kepala Sekolah dan masyarakat untuk mengembangkan pendidikan yang lebih sesuai dengan kebutuhan 
masing-masing daerah dalam mengelola sumber dayanya sendiri secara optimal.

Berdasarkan uraian tersebut di atas, maka penelitian ini akan berusaha mengkaji " Hubungan Implementasi Manajemen Berbasis Sekolah dengan Efektivitas Sekolah Menengah Atas Negeri se-Kota Palangkaraya".

\section{METODOLOGI}

Metode penelitian yang digunakan dalam penelitian ini adalah metode survey. Penelitian ini bersifat korelasional karena penelitian berusaha menyelidiki hubungan antar variabel penelitian yaitu variabel manajemen berbasis sekolah sebagai variabel prediktor dan efektivitas sekolah sebagai variabel kriterion. Studi korelasi ini akan menggunakan analisis korelasi dan regresi.

Populasi target dalam penelitian ini adalah guru-guru di SMA di Kota Palangkaraya di bawah naungan Dinas Pendidikan Kota Palangkaraya, berjumlah 163 orang yang tersebar pada 5 (lima) SMA Negeri.

Pengambilan sampel dengan teknik proporsional random sampling karena semua sampel mempunyai hak yang sama, yaitu pengambilan sampel yang didasarkan unit sekolah secara proporsional atau seimbang dan pengambilannya dilakukan secara random (tidak dipilih namun melalui undian) sehingga di dapat jumlah sampel sebanyak 115 orang guru.

Dalam penelitian ini terdapat dua data yang akan dikumpulkan, yaitu data implementasi manajemen berbasis sekolah, dan data efektivitas sekolah. Teknik pengumpulan data tentang efektivitas sekolah dan implementasi manajemen berbasis sekolah menggunakan metode tes dan kuesioner dengan Skala Likert. Selanjutnya kuesioner diujikan kepada para guru.

Dalam penelitian ini menggunakan tes dan kuesioner sebagai alat pengumpul data, yaitu soal tes variabel implementasi manajemen berbasis sekolah dan lembar kuesioner variabel efektivitas sekolah. Teknik pengumpulan data yang digunakan adalah data primer.

Analisis data dilakukan melalui tiga tahapan, yaitu tahap deskripsi data, tahap uji persyaratan analisis, dan tahap pengujian hipotesis.

\section{HASIL DAN PEMBAHASAN}

Deskripsi data yang akan disajikan dari hasil penelitian ini adalah untuk memberikan gambaran secara umum mengenai penyebaran data yang diperoleh dilapangan. Data yang disajikan berupa data mentah yang diolah menggunakan teknik statistik deskripsi. Adapun dalam deskripsi data ini yang disajikan dengan bentuk distribusi frekuensi, total skor, harga skor rata-rata, simpangan baku, modus, median, skor maksimum dan skor minimum yang disertai histogram. Deskripsi tersebut berguna untuk menjelaskan penyebaran data menurut frekwensinya, untuk menjelaskan kecenderungan terbanyak, untuk menjelaskan kecenderugan tengah, untuk menjelaskan pola penyebaran (maksimum-minimum), untuk menjelaskan pola penyebaran atau homogenitas data. Data tentang efektivitas sekolah diperoleh melalui kuesioner dan data tentang implementasi manajemen berbasis sekolah diperoleh melalui tes. Sampel yang diambil data dalam penelitian ini adalah 115 orang guru SMA Negeri se-Kota Palangka Raya. 
Mengenai data dari hasil penelitian variabel terikat yaitu Efektivitas sekolah $(\mathrm{Y})$ yang dijaring melalui penyebaran kuesioner, dengan jumlah pertanyaan sebanyak 33 butir instrumen dengan penggunaan skala pilihan jawaban skala lima (5 opsion), mempunyai skor teoretik antara 33 sampai 165 . Sedangkan skor empirik menyebar dari skor terendah 95 sampai dengan skor tertinggi 166 , dengan skor total yaitu 16184 , rata rata (M) 140,73, simpangan baku (SD) 11,081, modus (Mo) 144 median (Me) 143,00 dan varians 122,778 .

Mengenai data dari hasil penelitian mengenai variabel bebas yaitu Implementasi Manajemen Berbasis Sekolah (X) yang dijaring melalui penyebaran tes, dengan jumlah pertanyaan sebanyak 31 butir instrumen dengan penggunaan skala pilihan jawaban Benar dan Salah, mempunyai skor teoretik antara 0 sampai 31. Sedangkan skor empirik menyebar dari skor terendah 11 sampai dengan skor tertinggi 31 , dengan skor total yaitu 2724, rata rata (M) 23,68, simpangan baku (SD) 4,212, modus (Mo) 24, median (Me) 24,00 dan varians 17,743.

Uji normalitas distribusi frekuensi dari variabel $X$ dan $Y$ dilakukan dengan uji Lilliefors. Sesuai dengan ketentuannya, kriteria normalitas menurut uji Lilliefors adalah apabila nilai tertinggi dari $L_{\text {hitung }} \leq$ nilai Ltabel maka data berdistribusi normal.
Hasil perhitungan uji normalitas terhadap semua data dari masing-masing variabel pada taraf signifikansi 0,05 diperoleh hasil seperti tersaji pada tabel 1.

Berdasarkan tabel 1 dapat disimpulkan bahwa distribusi data variabel $X$ dan $Y$ berdistribusi normal, sehingga memenuhi persyaratan pengujian regresi dan korelasi.

\section{Uji Homogenitas Galat Taksiran Regresi $Y$ atas $X$}

Berdasarkan hasil perhitungan pengujian homogenitas tersebut seperti yang dijelasskan di atas diperoleh nilai $X^{2}$ hitung $=0,94382$ dengan $n=$ 115 dan taraf signifikan $\alpha=0,05$ diperoleh $x^{2}$ tabel $=$ 26,3 . Oleh karena $x^{2}$ hitung $<x_{\text {tabel, atau } 0,94382<}^{2}$ 26,3 dengan demikian maka semua data variabel efektivitas sekolah atas variabel implementasi manajemen berbasis sekolah adalah homogen.

Hipotesis dalam penelitian ini berbunyi Terdapat hubungan positif antara implementasi manajemen berbasis sekolah dengan efektivitas sekolah. Untuk pengujian hipotesis menggunakan analisis regresi dan korelasi sederhana terhadap dua variabel implementasi manajemen berbasis sekolah atas efektivitas sekolah menghasilkan arah regresi b sebesar 2,57 dan konstanta atau a sebesar 79,85. Maka dapat digambarkan bentuk hubungan antara kedua variabel tersebut oleh persaman regresi $\hat{Y}=a+b X=79,85+2,57 X$.

Tabel 1. Rangkuman Hasil Uji Normalitas Data Variabel X dan $Y$

\begin{tabular}{ccclc}
\hline Variabel & $L_{\text {hitung }}$ & $L_{\text {tabel }}$ & Keputusan & Kesimpulan \\
\hline$X$ & 0,08031 & 0,08264 & Terima Ho & Normal \\
$Y$ & 0,06532 & 0,08264 & Terima Ho & Normal \\
\hline
\end{tabular}


Selanjutnya untuk mengetahui derajat keberartian dilakukan Uji F, yang hasilnya dapat dirangkum pada tabel 2.

Dari nilai yang tertera pada tabel ANAVA untuk uji regresi sederhana diperoleh $\mathrm{F}_{\text {hitung }}=$ 20,796 untuk db pembilang adalah 1 dan $\mathrm{db}$ penyebut 113 , memiliki nilai yang lebih besar dari $F_{\text {tabel }}=3,49$ sedangkan untuk taraf signifikansi $1 \%$ diperoleh $F_{\text {tabel }}=6,90$. Dengan demikian dari kondisi ini disimpulkan bahwa koefisien arah dari regresi adalah signifikan atau sangat berarti.

Berdasarkan pada tabel ANAVA di atas untuk uji linieritas diperoleh nilai $F_{\text {hitung }}=-0,944$ untuk taraf nyata $5 \%$, diperoleh $\mathrm{F}_{\text {tabel }}=1,75$ dan selanjutnya untuk taraf nyata $1 \%$ diperoleh $\mathrm{F}_{\text {tabel }}=$ 2,26, untuk db pembilang 15 dan penyebut 98 .

Berpedoman pada nilai - nilai tersebut dapat disimpulkan bahwa regresi adalah berpola linier. Selanjutnya dari pengujian tersebut untuk persamaan regresi $\hat{Y}=a+b X=79,85+2,57 X$, dapat dipertanggung jawabkan untuk dijadikan alat dalam pengambilan keputusan.
Model hubungan antara variabel implementasi manajemen berbasis sekolah $(X)$ dengan efektivitas Sekolah ( $\mathrm{Y}$ ) dengan menggunakan model persamaan regresi $\hat{Y}=a+b X=79,85+2,57 X$ dapat digambarkan dalam grafik pada gambar 1 .

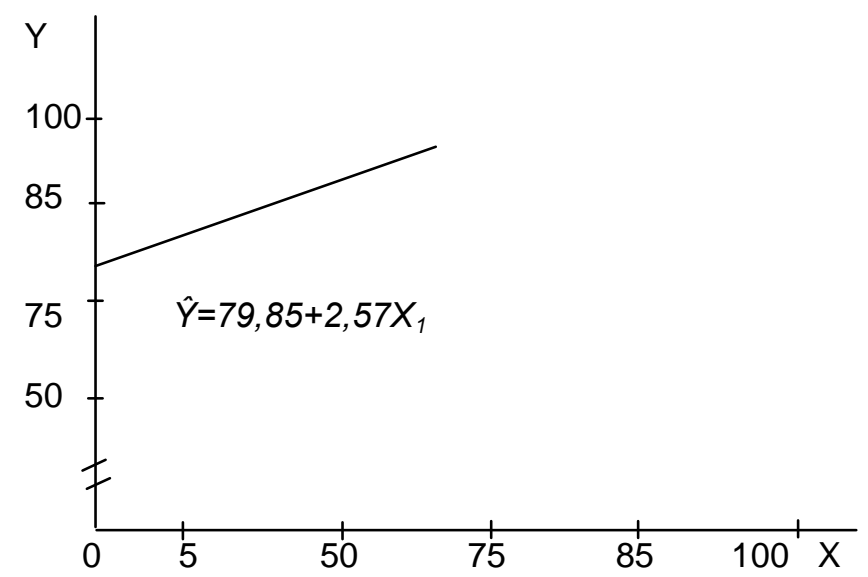

Gambar 1. Garis Regresi Hubungan Antara Implementasi Manajemen Berbasis Sekolah (X) dengan Efektivitas sekolah (Y)

Tabel 2. Daftar ANAVA untuk Uji Signifikansi dan Linieritas Regresi

\begin{tabular}{|c|c|c|c|c|c|c|}
\hline Sumber Varians & $\mathrm{db}$ & JK & RJK & $F_{\text {hitung }}$ & \multicolumn{2}{|c|}{$F_{\text {tabel }}$} \\
\hline Total & 115 & 2291578 & - & & 0,05 & 0,01 \\
\hline Regresi (a) & 1 & 2277581,35 & 2277581,35 & & & \\
\hline Regresi (b) & 1 & 13354,49 & 13354,49 & & & \\
\hline Sisa & 113 & 642,15 & 5,68 & $20,796^{\star *}$ & 3,94 & 6,90 \\
\hline Tuna Cocok & 15 & $-10640,16$ & $-709,34$ & $-0,944^{\mathrm{ns}}$ & 1,75 & 2,26 \\
\hline Galat & 98 & 11282,34 & 115,13 & - & & \\
\hline
\end{tabular}

Keterangan:

** : Regresi signifikan dengan $F_{\text {hitung }}=20,796>F_{\text {tabel }}=3,94$ pada $\alpha=0,05$

ns : Regresi linier dengan $F_{\text {hitung }}=-0,944<F_{\text {tabel }}=1,75$ pada $\alpha=0,05$

$\mathrm{db}=$ Derajat Kebebasan

$\mathrm{JK}=$ Jumlah Kuadrat

RJK = Rata-Rata Jumlah Kuadrat 
Persamaan regresi $\hat{Y}=a+b X=$ $79,85+2,57 X$ tersebut dapat untuk menjelaskan ramalan (forecasting). Dengan hasil pengujian tersebut, maka dinyatakan bahwa persamaan regresi $\hat{Y}=a+b X=79,85+2,57 X$ sangat signifikan dan linier, artinya setiap peningkatan satu skor implementasi manajemen berbasis sekolah $(\mathrm{X})$ akan diikuti oleh kenaikan efektivitas sekolah (Y) sebesar 2,57 dan pada konstanta 79,85 . Tingkat keeratan hubungan antara Implementasi manajemen berbasis sekolah (X) dengan Efektivitas sekolah (Y) ditunjukkan oleh Koefisien Korelasi $\left(r_{y}\right)$ sebesar 0,976 . Selanjutnya dilakukan uji signifikansi menggunakan uji-t yang hasilnya pada tabel 3 .

Berdasarkan tabel 3 tersebut dapat diketahui bahwa koefisien korelasi sangat signifikan. Hal ini karena t hitung 22,78 $>$ daripada $t$ tabel 1,66 pada $\alpha=0,05$ dengan $d b=113$. Maka dapat dikatakan bahwa hubungan antara Implementasi manajemen berbasis sekolah (X) dengan efektivitas sekolah $(\mathrm{Y})$ sangat signifikan. Temuan ini menyimpulan bahwa terdapat hubungan yang positif antara Implementasi manajemen berbasis sekolah dengan Efektivitas sekolah. Berarti makin baik pelaksanaan manajemen berbasis sekolah yang ditunjukkan dengan meningkatnya mutu pendidikan melalui kemandirian dan inisiatif sekolah dalam mengelola dan memberdayakan sumber daya yang tersedia. Hal ini disebabkan sumberdaya sekolah dikembangkan melalui kemandirian tatakelola keuangan sekolah, pemberdayaan masyarakat, penyediaan sarana dan prasarana pembelajaran dan sebagainya.

\section{Keterbatasan Penelitian}

Dalam melakukan penelitian masih terdapat berbagai kelemahan dan kekurangan, walaupun penulis telah berupaya semaksimal mungkin dengan berbagai usaha untuk membuat hasil penelitian ini bisa menjadi sempurna. Penulis menyadari bahwa keterbatasan penelitian ini antara lain : Pertama. Penelitian ini hanya membahas faktor faktor positif yang berhubungan dengan efektivitas sekolah, yaitu faktor implemenatasi manajemen berbasis sekolah, dan implementasi manajemen berbasis sekolah. Sedangkan secara obyektif masih banyak faktor lain yang mendukung efektivitas sekolah seperti iklim organisasi, motivasi kerja, komunikasi interpersonal, burn out, tekanan kerja/stres kerja, kompetensi/kemampuan guru dan sebagainya. Kedua. Sebelum melakukan penelitian penulis telah melakukan serangkaian uji coba untuk mendapatkan instrumen yang valid dan realiabel

Tabel 3. Uji Signifikansi Koefisien Korelasi Antara Implementasi Manajemen Berbasis Sekolah (X) dengan Efektivitas sekolah (Y)

\begin{tabular}{ccccc}
\hline $\mathrm{n}$ & Koefisien Korelasi (ry) & $\mathrm{t}_{\text {hitung }}$ & \multicolumn{2}{c}{$\mathrm{t}_{\text {tabel }}$} \\
\cline { 4 - 5 } 115 & 0,976 & $22,78^{\star *}$ & 1,66 & 0,01 \\
\hline
\end{tabular}

Keterangan :

$* *=$ Koefisien sangat signifikan $t$ hitung $(22,78)>t$ tabel $(1,66)$ pada

$\alpha=0,05$

$r_{y}=$ Korelasi $X$ dengan $Y$ 
sehingga instrument penelitian sudah layak untuk mengukur efektivitas sekolah dan implemenatasi manajemen berbasis sekolah namun demikian pengumpulan melalui kuesioner dan tes ini masih ada kelemahan-kelemahan seperti jawaban yang kurang cermat, responden yang menjawab asalasalan dan tidak jujur, serta pertanyaan yang kurang lengkap sehingga kurang dipahami oleh responden. Ketiga. Penulis mempunyai keterbatasan dalam melakukan penelaahan penelitian, pengetahuan yang kurang, literatur yang kurang, waktu dan tenaga, kelemahan dalam menterjemahkan naskah berbahasa Inggris ke Indonesia. Hal ini merupakan kendala bagi peneliti untuk melakukan penyusunan yang mendekati sempurna, namun demikian bukan berarti hasil penelitian tidak valid dan tidak reliable. Keempat. Terlepas dari adanya kekurangan namun hasil penelitian ini telah memberikan informasi yang sangat penting bagi perkembangan manajemen sekolah, guru, perkembangan dunia pendidikan dan penentuan keputusan dalam manajemen pendidikan yaitu ternyata terdapat hubungan yang positif dan signifikan antara implementasi manajemen berbasis sekolah $(X)$ dengan efektivitas sekolah $(\mathrm{Y})$.

\section{KESIMPULAN DAN SARAN}

\section{Kesimpulan}

Berdasarkan pelaksanaan penelitian dan hasil pengolahan data secara interpretasi data terhadap masing - masing variabel dan dimensi dimensi pada variabel - variabel tersebut dapat disimpulkan bahwa Terdapat hubungan signifikan antara Implementasi Manajemen Berbasis
Sekolah dengan Efektivitas sekolah pada SMA Negeri se-Kota Palangka Raya Kalimantan Tengah. Hal ini memberikan pengertian bahwa semakin positif atau semakain baik pelaksanaan manajemen berbasis sekolah, akan diiringi dengan meningkatnya efektivitas efektivitas sekolah. Demikian pula sebaliknya, apabila buruknya kualitas pelaksanaan manajemen sekolah, akan diiringi dengan menurunnya efektivitas dari efektivitas sekolah. Hubungan kedua variabel ini ditunjukkan oleh persamaan regresi sederhana $\hat{Y}=a+b X=79,85+2,57 X$ yang telah teruji linear dan signifikan. Kekuatan hubungan antara variabel $X$ dan $Y$ ditunjukkan oleh koefisien korelasi $r_{y}$ sebesar 0,976 sehingga kontribusi variabel $X$ terhadap $Y$ sebesar $95,26 \%$. Hal ini berarti $95,26 \%$ variasi nilai efektivitas sekolah ditentukan oleh implementasi manajemen sekolah.

\section{Saran}

Berdasarkan pembahasan hasil penelitian dan kseimpulan di atas, maka dapat diajukan saran - saran sebagai berikut:

1. Dalam rangka meningkatkan mutu pendidikan dengan pengelolaan sekolah secara efektif dan dan efisien serta sejalan dengan pelaksanaan desentralisasi pendidikan, para penyelenggara pendidikan baik di pusat, di daerah, maupun di sekolah perlu memperhatikan berbagai aspek yang berkenaan dengan input sekolah, kepuasan kerja guru, partisipasi orang tua siswa, dan iklim sekolah.

2. Sekolah harus banyak berkomunikasi, berinteraksi dengan masyarakat, baik melalui instansi resmi maupun tidak resmi, sehingga 
kebutuhan masyarakat dapat dipenuhi dan dapat memberi kesadaran kepada mereka tentang pentingnya meningkatkan kualitas pendidikan.

3. Implementasi MBS menciptakan rasa tanggung jawab melalui administrasi sekolah yang lebih terbuka. Kepala sekolah, guru, dan anggota masyarakat bekerja sama dengan baik untuk membuat Rencana Pengembangan Sekolah. Sekolah memajangkan anggaran sekolah dan perhitungan dana secara terbuka pada papan sekolah. Dengan keterbukaan ini akan meningkatkan kepercayaan, motivasi, serta dukungan orang tua dan masyarakat terhadap sekolah.

4. Manajemen Berbasis Sekolah merupakan gagasan yang perlu dijalankan dalam dunia pendidikan yang memberikan kesempatan pada pengelola sekolah untuk berkembang menurut potensi, kebutuhan, kreatif, inovasi yang dimilikinya.

5. Kepada guru disarankan untuk lebih memperdalam dan menguasai konsep manajemen berbasis sekolah dan harus lebih berkreasi dalam meningkatkan manajemen kelas.

\section{DAFTAR PUSTAKA}

Al-Qur'an terjemahan. Bandung: PT. Syaamil Cipta Media.

Anwar, Moch. Idhochi. 2003. Administrasi Pendidikan dan Manajemen Biaya Pendidikan. Bandung : CV. Alfabeta.

Danim, Sudarwan. 2003. Menjadi Komunitas Pembelajar; Kepemimpinan Transformasional dalam Komunitas Organisasi Pembelajaran. Jakarta: PT. Bumi Aksara.
. 2008. Kinerja Staf dan Organisasi, Bandung: Pustaka Setia.

Dewanto \& Tarsis Tarmudji. 1995. Metode Statistika. Yogyakarta: Liberty.

Ghozali, Abbas. Tinjauan Literatur : Effective School Research, Jurnal Pendidikan dan Kebudayaan, No. 021. Tahun ke-5, Januari 2000, Balitbang Depdiknas.

Gibson, Ivancevich, Donnelly. 1996. Organisasi, Perilaku, Struktur, Proses, (Alih

Bahasa Nunuk Adiarni), Jakarta: Penerbit Binarupa Aksara.

kedua. Yogyakarta: BPFE

Hall, John, et.al. 2002. Transformational Leadership: The Transformation of Managers and Associates. on line : www.edis.ifas.ufl.edu di akses pada minggu tanggal 4 April 2010

Hasibuan, Malayu. 2003. Organisasi dan Motivasi: Dasar Peningkatan

Produktivitas. Jakarta: Bumi Aksara.

Harefa, Andrias. Kepemimpinan-Manajemen: Visionaris. [Online].

http://www.pembelajar.com/pemimpin/pemi nari.htm di akses pada tanggal minggu 4 April 2010

Heidjrachman, H. Suad. 2002. Manajemen Personalia. Yogyakarta : BPFE

Komariah, Aan dan Triatna, Cepi. 2008. Visionary Leadership menuju Sekolah Efektif. Bandung: Rosdakarya.

Koster, Wayan.2001, Analisis Komparatif Antara Efektivitas sekolah dengan Sekolah

Tidak

Efektif, www.depdiknas.go.id/jurnal/12.htm Jum'at, 9 April 2010

Law, Sue \& Glover, Derek. 2000. Educational Leadership and Learning; practice, policy and research. Buckingham: Open university Press. 
Madhi, Jamal. 2001. Menjadi Pemimpin yang Efektif dan Berpengaruh Tinjauan Manajemen Kepemimpinan Islam. Bandung. PT Syamil Cipta Media.

Moeljono, Djokosantoso. 2009. More About Beyond Leadership; dua belas konsep kepemimpinan. Jakarta: PT. Elex Media Komputindo.

Nawawi, Hadari. 1989. Organisasi sekolah dan pengelolaan kelas sebagai lembaga pendidikan. CV. Haji Masagung. Jakarta.

Nawawi, Hadari dan Hadari, M. Martini. 2006. Kepemimpinan yang Efektif.

Yogyakarta: Gajah Mada University Press.

Nurgiyantoro, Burhan., dkk. 2004. Statistika Terapan untuk Penelitian IImu - IImu Sosial. Yogyakarta: Gajah Mada University Press.

Rahman, dkk. 2006. Peran Strategis Kapala Sekolah dalam Meningkatkan Mutu Pendidikan. Jatinangor: Alqaprint.

Rahman, Samson. 2006. Sukses Menjadi Pemimpin Islami. Jakarta: Maghfirah Pustaka.

Ramdhan, Muhammad. 2005. "Memimpin Sesuai Keadaan". Makalah, Jakarta

Rivai, Veithzal dan Mulyadi, Deddy. 2009. Kepemimpinandan Perilaku Organisasi, edisi ke tiga. Jakarta: PT. Rajagrafindo Persada.

Robbins, Stephen P. 2003. Organizational Behavior. New Jersey: Pearson Education International.

Scheerens, Jaap. 2003. Menjadikan Efektivitas sekolah. Jakarta: Logos.

Sastrodiningrat, Soebagio. 2002. Manajemen dan Kepemimpinan. Jakarta. IHC.

Siagian, Sondang P. 2002. Kiat meningkatkan Produktivitas kerja. Jakarta: Rineka

Cipta.
Sugiyono.2009. Metode Penelitian Pendidikan: Pedekatan Kuantitatif, Kualitatif,danR\&D.Bandung: Alfabeta

Toha, Miftah.1990. Kepemimpinan Dalam Manajemen, Jakarta : Rajawali Pers, cet. $\mathrm{Ke}-4$,

Wahab, Abdul Azis. 2008. Anatomi Organisasi dan Kepemimpinan Pendidikan (Telaah terhadap Organisasi dan Pengelolaan Organiosasi Pendidikan). Bandung: Alfabeta.

Wahjosumidjo. 2003. Kepemimpinan Kepala Sekolah, Tinjauan Teoritik dan

Permasalahannya. Jakarta: PT Raja Grafindo Persada.

Yukl, Gery. 2005. Kepemimpinan dalam Organisasi, edisi bahasa Indonesia. Jakarta: PT. Indeks kelompok Gramedia. 